1994-9

\title{
The Effects of Gender on Career Decision Problems in Young
}

\section{Adults}

Jeffry H. Larson

Brigham Young University - Provo

Mark Butler

Brigham Young University - Provo, mark.butler@byu.edu

Stephan Wilson

University of Kentucky

Nilufer Medora

California State University, Long Beach

Scot Allgood

Utah State University

Follow this and additional works at: https://scholarsarchive.byu.edu/facpub

Part of the Other Social and Behavioral Sciences Commons

\section{Original Publication Citation}

Larson, J. H., Butler, M. H., Wilson, S., Medora, N., \& Allgood, S. (1994). The effects of gender on career decision problems in young adults. Journal of Counseling and Development, 73 (September/October), 79-84.

\section{BYU ScholarsArchive Citation}

Larson, Jeffry H.; Butler, Mark; Wilson, Stephan; Medora, Nilufer; and Allgood, Scot, "The Effects of Gender on Career Decision Problems in Young Adults" (1994). Faculty Publications. 4434.

https://scholarsarchive.byu.edu/facpub/4434

This Peer-Reviewed Article is brought to you for free and open access by BYU ScholarsArchive. It has been accepted for inclusion in Faculty Publications by an authorized administrator of BYU ScholarsArchive. For more information, please contact ellen_amatangelo@byu.edu. 


\title{
The Effects of Gender on Career Decision Problems in Young Adults
}

\author{
Jeffry H. Larson, Mark Butler, Stephan Wilson, Nilufer Medora, and Scot Allgood
}

\begin{abstract}
The authors investigated gender differences in psychological problems in the career decision making (CDM) process of young adults. Specifically, problems with decision anxiety, life-goal awareness, luck-fate orientation, authority orientation, and secondary gain motivation were investigated. Methodology involved administering the Career Decision Diagnostic Assessment (CDDA) instrument to 1.006 college students from four universities. Results indicated no gender differences in giobal levels of problems in CDM. Women reported more problems with life-goal awareness and authority orientation than did men. Men reported more problems with secondary gain motivations than did women. The results are discussed in terms of implications for gender-differentiated career counseling
\end{abstract}

ti $\mathrm{n}$ the last two decades, career counselors have become more sensitized to women's career development as a process separate and different from men's career development (Fitzgerald \& Betz, 1983). Numerous scholars have advocated the development of a unique theory to explain women's complex career development process (Astin, 1984; Brooks, 1984; Fitzgerald \& Betz, 1983; Perun \& Bielby, 1981). Subsequent research has focused primarily on women's career development separate from that of men's; the result is an abundance of studies documenting within-sex differences in career development and a lack of research examining between-sex differences (Fitzgerald \& Betz, 1983; Moreland, Harren, Krimsky-Montague, \& Tinsley, 1979). Because an understanding of relevant gender differences in career development facilitates accurate counselor intervention, there is definitely a need for research in this area.

Additionally, the existing research literature in career decision making is predominantly oriented to answering content or outcome questions, or the "what" of career decision making, rather than considering process-oriented questions such as "How do individuals make career decisions?" and "What kinds of problems do they encounter in the process?" (Fitzgerald \& Betz, 1983; King, 1989; Moreland et al., 1979). This omission also seems significant because most career counseling is at the level of process rather than outcome.

Despite the need for studies of gender differences in career decisionmaking problems, only one study has specifically investigated gender differences (Hartman, Jenkins, Fuqua, \& Sutherland, 1987). Hartman et al. (1987) found no difference between male participants' and female participants' total scores on a measure of career indecision, but found that women were more likely than were men to perceive "external barriers and a need for support in making career decision" (p. 1104). They emphasized the need for further research to differentiate the factors that cause career indecision for both sexes. The purpose of this study was to identify gender differences in psychological problems encountered in the career decision-making process. We anticipated that the results would give career counselors more direction in the development of intervention strategies for career decision problems.

\section{REVIEW OF 'THE LITERATURE}

Recent research suggests several psychological problems that may affect individuals who struggle with a career decision. Anxiety (especially trait anxiety), one of the first factors identified as causing problems in career decision making (CDM; Bansberg \& Sklare, 1986; Fuqua, Blum, \& Hartman, 1988; Newman, Fuqua, \& Seaworth, 1989), is the affective symptom of an internal struggle that blocks CDM. A poorly formed sense of self or lack of identity and life-goal awareness inhibits CDM because much of the CDM process involves identifying which alternative(s) best fulfills one's needs and preferences (Fuqua et al., 1988). For individuals unsure of who they are, career choice is a secondary issue (Bansberg \& Sklare, 1986; Chickering, 1969). The relationship of locus of control to CDM is well documented (Bansberg \& Sklare, 1985; Fuqua et al., 1988; Taylor, 1982). Compared with individuals with an internal locus of control, individuals with an external locus of control feel unable to influence the future, and thus CDM may be left to luck and fate of dependence on authority figures (e.g., parents or counselors; Bansberg \& Sklare, 1986; Fuqua et al., 1989). Finally, CDM may be inhibited by a secondary gain motivation (Bansherg \& Sklare, 1986), which refers to some perceived advantage that an individual gains by not making a commitment to a career decision. It may involve conscious or unconscious motivations such as nonconformity or fear that one cannot change a career choice once it has been made.

Significant differences exist in the structure of men's and women's career development (Brooks, 1984; Corder \& Stephan, 1984; Fitzgerald \& Betz, 1983) that may lead to significant gender differences in the CDM process (Bem, 1981) and result in different problems in CDM. The main difference in the structure of men's and women's career development is the isolated decision presented to men, as opposed to the dichotomous decision presented to women (Corder \& Stephan, 1984; Kriger, 1972). Men are socialized primarily to be the family financial provider, a role expressed through career endeavors; consequently, men's family and career obligations run parallel except where secondary nurturant-expressive roles conflict with career efforts (Diamond, 1987; Eccles, 1987). Thus, CDM simultaneously fulfills both family and career imperatives for men. In contrast, women often perceive that family and career operate in a zero-sum equation. Because women are socialized to perform the primary family role of nurturant care giver, a role expressed through interactions within the family, career investment often constitutes a perceived family debt. Thus, women's unique perspective is of family and career not parallel with each other, but in conflict (Apter, 1985; Fox \& Hesse-Biber, 1984; McGoldrick, 1987). Women's reconciliation of competing family and career aspirations and opportunities constitutes the structural dichotomy of women's CDM 
Research supports this dichotomous model. Women are more likely than are men to anticipate the need to modify career goals and commitment to meet marriage and family priorities (Archer, 1985; Ginzberg, 1984; Herzog \& Bachman, 1982; Tittle, 1981; Veroff, 1983). Anticipating parenthood, young men ex pect to invest more fully in their career, whereas young women expect to withdraw temporarily from their careers (Leslie, 1986; Tittle, 1981). Family life, traditionally a minor factor in men's career development, is a critical competing factor for women (Larwood \& Gutek, 1987).

Women's structural dichotomy additionally demands negotiating a good market "fit" (Almquist \& Angrist, 1970; Corder \& Stephan, 1984). Women who hope to combine significant family and career aspirations, as most do (Greenglass \& Devins, 1982), are structurally limited to careers that accommodate compromised allegiance. Thus, market barriers may cause women to circumscribe either family aspirations or their range of career opportunities (Fitzgerald \& Betz, 1983).

CDM problems also may vary by gender as a function of socialization or psychological differences between men and women. Women generally manifest somewhat higher anxiety levels than do men (Maccoby \& Jacklin, 1974; Tyler, 1965). Reports of lower self-efficacy in women as compared with men (Hackett \& Betz, 1981; O'Hare \& Beutell, 1987) support the theory that women have higher anxiety levels because they perceive a loss of control in vital areas of life (Bandura, 1977). Role conflict and anxiety are anticipated effects of the tenuous compromise between the unyielding demands of family and career. Fear. of success, an internal psychological barrier unique to women's career development, also leads to anxiety and is probably caused by the zero-sum equation of women's CDM (Farmer, 1976). Women may fear. that success in career endeavors threatens marital or other affiliative opportunities (Leslie, 1986; Paludi \& Fankell-Hauser, 1986). When career and family success are perceived as mutually exclusive, the ensuing dilemma may leave women vulnerable to anxiety (Fitzgerald \& Betz, 1983; Hoffman, 1977), especially during college years when both imperatives are concurrently salient (Ginzberg, 1984; Veroff. 1983).

The structural dichotomy of women's CDM also may negatively affect life-goal awareness. First, most women anticipate spending no more than one half of their time in career endeavors (Greenglass \& Devins, 1982) and expect to remain in the home while children are young (Leslie, 1986; Parsons \& Goff, 1980; Tittle, 1981). In contrast. for men, parenthood provokes more intense career involvement (Leslie. 1986; Tittle, 1981). With their anticipation of family endeavors occupying a prominent and early position, women may fail to invest thoroughly in an inner search for career self-definition; thus, career identity may be in a state of diffusion (Archer, 1985). Second, women perceive career decisions as being partially contingent on future marital realities (Bardwick \& Douvan, 1972; Epstein, 1970), which may prevent committed planning and exacerbates problems with life-goal awareness. A third impact of women's CDM dichotomy on life-goal awareness arises from the still-limited range of career alternatives for most women (Coleman, 1988). Moderate career-salient women may feel externally limited to fields that accommodate balanced allegiance. They may be internally limited to career areas that they have been socialized to consider. These external and internal barriers may encourage less introspection and, thus, less life-goal awareness.

Women's affiliative-based fear of success, intensified by the simultaneous peaking of both career and marital concerns and imperatives during the college years (Ginzberg, 1984; Veroff, 1983), is the fourth factor that may negatively affect women's career identity development.
Fear of affiliative costs of success may generate avoidance of career exploration, measured as decreased life-goal awareness (Taylor, 1982).

A luck or fate orientation relative to CDM is represented by resignation to "whatever happens," with the belief that the locus of control is external to oneself (Bansberg \& Sklare, 1985). Women's dichotomous CDM structure, together with external attribution styles (Cellini \& Kantorowski, 1982), lower self-efficacy (O'Hare \& Beutell, 1987), and external locus of control (Lopez \& Staszkiewicz, 1985) and the external limitations of career options already noted, may predict a gender-differentiated luck-fate orientation over the CDM process.

Predictions of gender-differentiated authority orientation can be generated from Gilligan's (1982) theory of gender-differentiated social development. Girls' primary experience of attachment, the relative equality of their relationship with their mothers, and the mother's continuous presence generate a fundamental orientation toward relationships and connectedness. In contrast, boys' experience with their fathers includes inequity and separation, because their fathers exercise greater power and are more frequently absent. Thus, men's development may be characterized by relatively more individuation and independence (Erikson, 1975; Marcia, 1980; Miller, 1976; Rosenberg \& Simmons, 1975). Hoffman (1972) emphasized that women's greater affiliative needs may exert a mediating influence on decisions. Thus, we anticipated that as compared with men, women may demonstrate more susceptibility to relational influences and pressures, translated here as dependence on authority in CDM. Research on gender differences in influenceability and support-seeking behavior equivocally supports this theory (Eagly \& Carli, 1981; Ward, Seccombe, \& Bendel, 1988). In a study of coping factors related to CDM, women reported support-seeking behavior more frequently than did men during the CDM process (O'Hare \& Beutell, 1987).

Unfortunately, no empirical literature directly addresses "hidden motivations" as problems in CDM. The foregoing review, however, suggests some potential for gender-differentiated secondary gain motivations. These predictions arise from women's dichotomous CDM structure and their stronger relationship orientation as compared with men's. The offspring of this zero-sum structure and relational sensitivity for women may be an increased potential for secondary advantage through postponing CDM.

\section{Research Questions}

Research in the areas of psychological gender differences, women's dichotomous CDM structure, and external limitations in the career market for women suggests that as compared with young adult men, young adult women may experience more CDM problems. The purpose of this study was to answer the following questions:

As compared with young adult men, will young adult women report the following:

1. More decision anxiety in CDM?

2. More problems with life-goal awareness in CDM?

3. More problems with a luck-fate orientation to CDM?

4. More problems with an authority orientation to CDM?

5. More problems with secondary gain motivations in CDM?

6. More CDM problems in general?

In addition to comparing young men and women on these different kinds of CDM problems, it was important to determine the frequency of such problems in a sample of university undergraduates. 


\section{METHOD}

\section{Participants}

Participants for this study were 1,006 college students from four major universities ( $n=350,321,173$, and 162). The sample consisted of 454 men $(45 \%)$ and 552 women (55\%). The mean age for the students was 19 years (range $=17$ to 23 years). The mean family income was $\$ 49,500$. Of the total 1,006 students, 520 were freshmen $(52 \%), 340$ were sophomores (33\%), and 146 were first-semester juniors (12\%). The sample was mostly Caucasian (89\%), but the following other groups were also represented: Asian Americans (6\%), Hispanics (3\%), and African Americans (2\%).

\section{Instruments}

Students completed a short questionnaire on demographic data. Career decision problems (i.e., decision anxiety, life-goal awareness, luck-fate orientation, authority orientation, and secondary gain motivation) were measured using the Career Decision Diagnostic Assessment (CDDA) instrument (Bansberg \& Sklare, 1986). The CDDA identifies psychological blocks to CDM (Bansberg \& Sklare, 1986) and was developed to diagnose both intrapersonal and interpersonal CDM problems.

The CDDA is a self-report written instrument consisting of 37 items. The first item asks individuals if they have made a specific decision about a career choice or change. The second item asks them how certain they are in their choice of a career. Items 3 through 36 consist of statements about CDM to which participants indicate their degree of agreement or disagreement on a 6-point Likert scale (ranging from strongly agree to strongly disagree). The last item asks if the person has answered each of the items honestly. The test takes approximately 15 to 20 minutes to complete.

The CDDA provides a total career decision problems score (range is 36 to 180) and five subscale scores. These subscales are the following: Decision Anxiety (range is 9 to 54), Life-Goal Awareness (range is 7 to 42), Luck and Fate Orientation (range is 7 to 42), Authority Orientation (range is 5 to 30), and Secondary Motivation (range is 6 to 36). Bansberg and Sklare (1986) provided cut-off scores for the identification of individuals in the lower, middle, and high ranges of scores.

Bansberg and Sklare (1986) reported internal consistency reliability for the total test as $r=.94$ (Cronbach's alpha); the alpha levels for the subtests ranged from $r=.76$ to $r=89$. In this study the internal consistency reliability coefficients (Cronbach's alpha) for the CDDA subscales were as follows: Decision Anxiety-.86, Life-Goal Awareness--.82, Luck-Fate Orientation-.79, Authority Orientation--.84, Secondary Gain-.75, and Total Scale-.92.

Bansberg and Sklare (1986) and Larson, Busby, Wilson, Medora, and Allgood (1994) reported construct validity and convergent and discriminant validity for the CDDA and its subscales. More specifically, Bansberg and Sklare (1986) provided evidence for construct validity by submitting the CDDA items to a factor analysis procedure (with an oblique rotation) with a sample of high school and community college students. Larson et al. (1994) used an identical factor analysis procedure with a sample of university students. Their results supported the results of Bansberg and Sklare (1986; i.e., it seems that the CDDA subscales are able to distinguish between the five different CDM problem constructs investigated in this study).

Evidence for convergent validity was provided by Larson et al. (1994) who found a significant positive correlation $(r=.71)$ between the CDDA total score and the Career Decision Scale total score (CDS; Osipow, 1980). The CDS is one of the most widely used measures of career indecision (Slaney, 1988). Bansberg and Sklare (1986) computed correlations between the CDDA total score and subscale scores and select scores on the Strong-Campbell Interest Inventory (SCII; Strong, Hansen, \& Campbell, 1985) to show evidence of discriminant validity for the CDDA. They found that a high score on the CDDA correlated significantly $(r=.24)$ with a high number of dislikes on the SCII. This was interpreted to mean that "individuals with psychological blocks to CDM may not be ready to take an interest inventory and therefore, their interest profiles may not show unclear or unuseful results"' (Bansberg \& Sklare, 1986, p. 7). In addition, high authority orientation scores were correlated significantly $(r=-.24)$ with low overall general interest themes on the SCII; high decision anxiety scores were significantly correlated $(r=-.23)$ with academic comfort on the SCII. (See Larson et al. [1994] for a more detailed description of the psychometric properties of the CDDA.)

Bansberg and Sklare (1986) described the five CDDA subscales as follows:

1. Decision anxiety: The degree of internal struggle or ambiguity and individual experiences regarding the CDM process. This internal struggle immobilizes an individual who is progressing toward career selection (e.g., "There is one part of me that wants to commit myself to a career/job choice and another part of me that is afraid to commit myself to a career/job choice").

2. Life-goal awareness: The degree of knowledge, understanding, and insight that an individual possesses in regard to what it is that he or she wants and needs out of life (e.g., "I can name the three most important things that I need in a career/job to be satisfied").

3. Luck-fate orientation: The degree of belief that an individual has in the existence of luck or fate as the prime determinant in ultimate success or failure in life (e.g., "I don't think career planning really makes a difference. Ultimately, the job I end up with will be the result of luck or opportunity"').

4. Authority orientation: The degree of dependence or desire individuals have for an authority figure to make decision for them (e.g., "My parents [or spouse, family, etc.] know better than I what is the best choice for me on important decisions").

5. Secondary gain: The degree of advantage or gain that an individual receives by not making a commitment to a career decision. The etiology of secondary gain may involve conscious or unconscious motivations (e.g., "I have something to lose by making a career/job choice at this time").

\section{RESULTS}

Although Bansberg and Sklare (1986) reported a mean correlation between the CDDA subscales of $r=.46$, a slightly higher correlation $(r=.53)$ was found in this study. Because the subscales were moderately correlated, Haase's (1980; Haase \& Ellis, 1987) method of controlling for experiment-wise error was used. This method for determining alpha is based on the number of dependent variables (five in this study), the degree of intercorrelation between the dependent variables $(r=.53$ in this study), and the sample size $(N=1,006)$. No individual effects ( $t$ tests) were considered significant unless $p<.012$. The values for each significant $t$ test in this study were highly significant $(p<.005$ in every case).

Table 1 shows the mean scores and standard deviations for the CDDA subscales and the total scale by sex. Higher scores reflect greater problems on each subscale and for the total scale. There was no significant difference between the mean scores of men and women on the Decision Anxiety subscale of the CDDA. The women's Life-Goal Awareness mean score was significantly higher than was the men's mean score $(p=<.005)$. There was no significant difference between the men and women on the Luck-Fate Orientation subscale of the CDDA 


\section{TABLE 1}

\section{Mean Scores ${ }^{\star}$ and Standard Deviations for the CDDA for young Adult Male and Young Adult Female Students and $T$ Tests for Gender Differences}

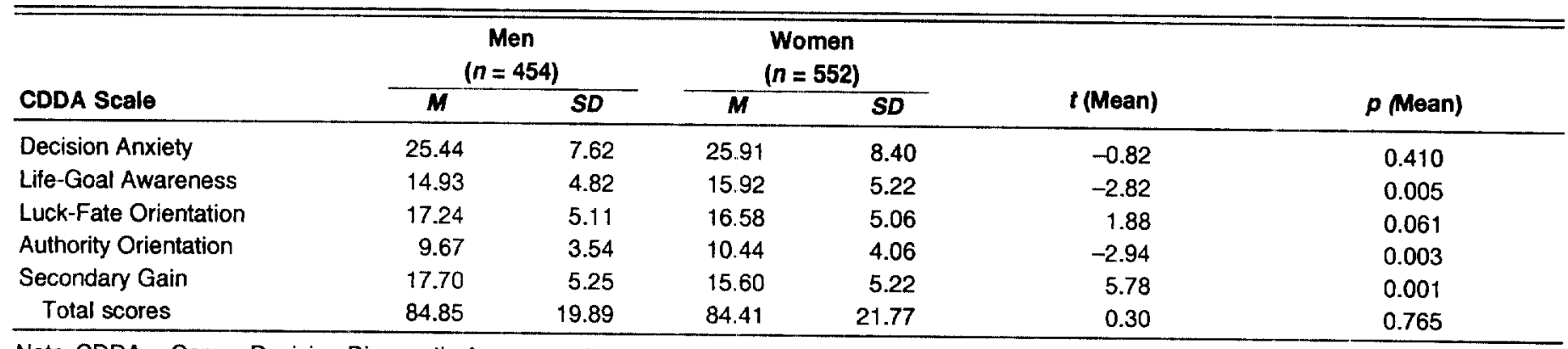

Note. CDDA = Career Decision Diagnostic Assessment.

"The higher the score on a CDDA subscale, the greater the career decision problem.

$(p=<.003)$. Men scored significant higher than did women on the Secondary Gain subscale $(p=<.001)$. The total CDDA mean scores for men and women were not significantly different.

In addition to gender differences, results are included in Table 2 that should be of interest to career counselors. Table 2 reports the percentage of male and female students with CDDA subscale scores and total scores in the high range. (The cutoff scores for high-range scores are equal to approximately one standard deviation above the mean score for each subscale.) Scores in this range indicate a high probability of a CDM problem in that area and a need for career counseling in relation to the specific problem identified by the respective subscale score (Bansberg \& Sklare, 1986). Results showed that a significant number of both male $(38 \%)$ and female (37\%) students may benefit from career counseling for problems with decision anxiety. A relatively equal percentage of male $(22 \%)$ and female (20\%) students reported problems with secondary gain motivations in CDM. About equal numbers (11\%) of students reported problems with an authority orientation and a luck and fate orientation to CDM. A minority of students $(6 \%)$ reported problems with life-goal awareness. Total CDDA scores revealed that $19 \%$ of male and female students reported various psychological problems in CDM.

\section{TABLE 2}

\section{Percentage of Students With CDDA Scores in the High Range*}

\begin{tabular}{|c|c|c|c|c|}
\hline \multirow[b]{2}{*}{ CDDA Scale } & \multicolumn{2}{|c|}{$\begin{array}{c}\text { Men } \\
(n=454)\end{array}$} & \multicolumn{2}{|c|}{$\begin{array}{c}\text { Women } \\
(n=552)\end{array}$} \\
\hline & $\%$ & $\mathbf{n}$ & $\%$ & $n$ \\
\hline Decision Anxiety & 38 & 172 & 37 & 204 \\
\hline Life-Goal Awareness & 6 & 27 & 5 & 28 \\
\hline Luck-Fate Orientation & 12 & 54 & 10 & 55 \\
\hline Authority Orientation & 11 & 50 & 13 & 72 \\
\hline Secondary Gain & 22 & 100 & 20 & 110 \\
\hline Total scores & 19 & 86 & 19 & 105 \\
\hline
\end{tabular}

Note. See Table 1 Note.

"High range scores indicate a need for career counseling.

\section{DISCUSSION}

The results here raise new and pertinent questions relative to postulated links between women's dichotomous CDM and their CDM problems. These provocative questions are considered after we discuss specific results of each CDDA subscale.

For problems with decision anxiety, the observed difference in mean scores for young adult men and women was not significant. This unexpected result may be explained by other factors arising from women's dichotomous CDM structure. Increased anxiety consequent to women's frustrations over balancing family and career opportunities and goals is perhaps counterbalanced by an attendant calm that their career is not the sole focus of their life's work. Consequently, although for many men CDM may generate anxiety over the pressing need to "make the right choice," women may feel less intense pressure to settle immediately on a perfectly compatible career choice. This is only a tentative explanation for the results. Future research is needed to provide evidence for this explanation. Qualitative research (e.g., interviewing) should focus on contemporary young adults' psychological investment in career versus marriage during the early college years and how this investment affects decision anxiety for both sexes.

The significant differences in the mean levels of reported problems with life-goal awareness were small and may not be practically significant. Women's problems with life-goal awareness may arise from their unique CDM structure, which sometimes hinders committed career planning. Women anticipating a relatively equal balance between family commitment and career commitment who anticipate an ascendancy of family priorities probably feel the least pressure to engage in introspection leading to realistic, specific CDM.

There was no difference between the men's and women's observed mean scores on the Luck-Fate Orientation subscale of the CDDA. Although women's problems with luck-fate orientation may arise from their dichotomous CDM structure, men may encounter other conditions generating equally significant problems. This study supports Lunnegorg's (1978) study, which found no gender differences in dependency in CDM with a sample of high school and first-and second-year college students. Dependency, defined as projecting responsibility for decisions outside oneself and being strongly influenced by one's environment, overlaps somewhat with the CDDA Luck-Fate Orientation subscale 
items, such as "Usually, I find the best solution to problems, such as career/job choices, is to let them solve themselves."

Differences in authority orientation were significant, but small, with women reporting greater authority orientation than did men. These results are inconsistent with Lunneborg's (1978) finding of no gender differences in dependency in CDM. As noted earlier, his conceptualization of dependency included both being heavily influenced by one's environment and projecting responsibility for decisions outside oneself. With this definition manifesting both dependency and luck-fate features, a more discriminating conceptualization of dependency by Lunneborg would be necessary before either results are discounted. Until then, it is tentatively assumed that authority orientation as defined by the CDDA may indeed be a greater problem in CDM for women than for men. This study supports O'Hare and Beutell's (1987) finding of significant gender differences in support-seeking behavior from family and friends in CDM.

Reports of secondary gain motivation problems revealed that men were significantly more likely than were women to experience these problems. For men, significant conflicts may exist between their interest in reaching a career decision and opposing interests in not making a career decision. Although for women, career choice is only one aspect of their identity, for men it may overshadow all other features of personal identity (Carter \& McGoldrick, 1988); consequently, there may be significant secondary gain motivation for men postponing CDM. First, they may avoid CDM in order not to commit prematurely to a less than completely compatible academic and career course that will later occupy most of their waking hours. For examples, first, an individual may postpone CDM for fear of making a wrong choice, which would then mean "wasting his college years preparing for the wrong career." Second, when a man pursues a career not traditionally esteemed in terms of power, prestige, prosperity, or security (e.g., law, business, or medicine), he may postpone concrete action or public declaration of his goal, fearing the disapproval of parents, dating partner(s), or friends. For women, on the other hand, it may be that only the second motivation operates in postponing CDM, because a less than perfect career choice is probably less threatening and is an accepted compromise for women who anticipate balancing family and career goals. Future research should focus on the validity of these reasons for greater secondary gain motivation for men as compared with women.

Overall, reports of problems in CDM showed no significant differences between men and women for total CDDA scores. This result supports the findings of Hartman, Jenkins, Fuqua, and Sutherland (1987) who found no significant difference between college men and women on the total scores of the CDS. The CDS (Osipow, Carney, Winer, Yanico, \& Koschir, 1976) measures an individual's degree of educational and vocational indecision based on mostly cognitive sources (e.g., lack of information about careers, abilities and interests).

The results of this study should be considered in the context of three limitations. First, the sample in the study was a nonrandom sample that is not representative of the general population. Second, there is a limitation of using gender by itself to explain differences in CDM problems. Other variables like gender role attitudes, self-esteem, maternal employment, and support from significant others may also account for differences in CDM problems (Corder \& Stephan, 1984). Third, the women in the sample may have experienced the dichotomous CDM structure in greatly varying degrees. This factor was not controlled for in this study, but should be in future research. The women scored significantly higher than did men on only two of the five CDDA subscales, and the mean score differences were not large (e.g., the differences in mean Authority Orientation scale scores were less than
1 point). These small differences found in a large sample are not practically significant enough to encourage gender-differentiated career counseling yet. Replication of this study is necessary before considering such approaches.

Instead of anticipating considerable overall gender differences in CDM problems, career counselors should direct their attention to the specific type and etiology of problems. Although the intensity of overall problems for male and female students seems to be similar, more research is needed to determine if the type, etiology, and course of those problems may be gender differentiated as suggested by this study.

The frequency of CDM problems demonstrated in this study warrants special attention. Significant numbers of young adult male and female students reported specific CDM problems. Career counselors need to be aware of the etiologies and potentially debilitating effects of problems measured by each of the CDDA subscales. Most important, this study indicates that career counselors should especially attempt to alleviate or manage decision anxiety and help students with secondary gain motivation difficulties. Decision anxiety is a well-known inhibitor of effective CDM (Fuqua \& Hartman, 1983; O'Hare \& Tamburri, 1986) and was reported as a problem by a large number of undergraduate students in this study. In contrast, little is known about secondary gain motivations, the nature of which would become evident with more in-depth career counseling. Students were less likely to present luck-fate orientation, authority orientation, and life-goal awareness problems.

This study, limited in its scope, has somewhat disconfirmed gender difference expectations and has indicated that women's unique CDM structure and other psychological factors do not necessarily generate greater overall levels of CDM problems for women than for men. Although this result is gratifying, career counselors may benefit from further exploration of the links suggested here between women's unique CDM problems and their unique CDM structure, socialization, and psychosocial development. If supported, such differential etiologies for men's and women's CDM problems may indicate differential career counseling and career education.

\section{REFERENCES}

Almquist, E. M., \& Angrist, S. S. (1970). Career salience and atypicality of occupational among college women. Joumal for Marriage and the Family, $32,242-249$

Apter, T. (1985). Why women don't have wives: Professional success and motherhood. New York: Schocken Books.

Archer, S. L. (1985). Career and/or family: The identity process for adolescent girls. Youth and Society, 16, 289-314.

Astin, H. A. (1984). The meaning of work in women's lives: A sociopsychological model of career choice and work behavior. The Courseling Psychologist. $12,117-126$.

Bandura, A. (1977). Self-efficacy: Toward a unifying theory of behavioral change. Psychological Review, 84, 191-215.

Bansberg, B, \& Sklare, J. (1986). The Career Decision Diagnostic Assessment Monterey, CA: McGraw-Hill.

Bardwick, J.S., \& Douvan, E. (1972). Ambivalence: The socialization of women. In J. M. Bardwick (Ed.), Readings on the psychology of women (pp. 52-57). New York: Harper \& Row.

Bem, S. L. (1981). Gender schema theory: A cognitive account of sex typing Psychological Review, 88, 354-364.

Brooks, L. (1984). Counseling special groups: Women and ethnic minorities. In D. Brown, L. Brooks, \& Associates (Eds.), Career choice and development (pp. 355-368). San Francisco, CA: Jossey-Bass

Carter, B., \& McGoldrick, M. (Eds.). (1988). The changing family life cycle: A framework for family therapy (2nd ed.). New York: Gardner Press.

Cellini, J. V., \& Kantorowski, L. A. (1982). Internal-external locus of control: New normative data. Psychological Reports, 51, 231-235.

Chickering, A. (1969), Education and identity. San Francisco, CA: Jossey-Bass. 
Colernan, J. C. (1988). Intimate relationships, marriage and the family. New York: Macmillan.

Corder. J., \& Stephan, C. W. (1984). Females' combination of work and family roles: Adolescents' aspirations. Journal of Marriage and the Family, 46. $391-402$.

Diamond, E. E. (1987). Theories of career development and the reality of women at work. In B. A. Gutek \& L. Larwood (Eds.), Women's career development (pp. 15-27). Newbury Park, CA: Sage.

Eagly, A. H., \& Carli, L. L. (1981). Sex of researchers and sex-typed communications as determinants of sex differences in influenceability: A meta-analysis of social influence studies. Psychological Bulletin, 90, 1-20.

Eccles, J. S. (1987). Gender roles and women's achievement-related decision. Psychology of Women Quarterly. 11, 135-171

Epstein, C. F. (1970). Woman's place: Options and limitations in professional careers, Berkeley, CA: University of California.

Erikson, E. H. (1974). Life history and the historical moment. New York: Norton.

Farmer, H. S. (1976). What inhibits achievement and career motivation in women? The Counseling Psychologist, 6, 12-15.

Fitzgerald, L. F., \& Betz, N. E. (1983). Issues in the vocational psychology of women. In W. B. Walsh \& S. H. Osipow (Eds.), Handbook of vocational psychology: Vol I. Fondations (pp. 83-159). Hillsdale, NJ: Erlbaum.

Fox, M. F., \& Hesse-Biber, S. (1984). Women at work. Mayfield Publishing Company.

Fuqua, D. R., Blum, C. R., \& Hartman, B. W. (1988). Empirical support for the differential diagnosis of career indecision. The Career Development Quarterly, 36, 27-29.

Gilligan, C. (1982). In a different voice. Cambridge, MA: Harvard University.

Ginzberg, E. (1984). Career Development. In D. Brown, L. Brooks, \& Associates (Eds.), Career choice and development (pp. 169-191). San Francisco, CA: Jossey-Bass.

Greenglass, E. R., \& Devins, R. (1982). Factors related to marriage and career plans in unmarried women. Sex Roles, 8, 57-71.

Haase, R. F. (1980). Experiment-wise error rate protection in multi-variable univariate analysis. Duplicated manuscript, State University of New York at Albany.

Haase, R. F., \& Ellis, M. V. (1987). Multivariate analysis of variance. Journal of Counseling Psychology, 34, 404-413.

Hacket, G., \& Betz, N. E. (1981). A self-efficacy approach to the career development of women. Journal of Vocational Behavior, 18, 326-339.

Hartman, B. W., Jenkins, S. J., Fuqua, D. R., \& Sutherland, V. E. (1987). An analysis of gender differences in the factor structure of the Career Decision Scale. Educational and Psychological Measurement, 47, 1099-1106.

Herzog, A. R., \& Bachman, J. G. (1982). Sex-role atitudes among high school seniors. Ann Arbor. MI: Institute for Social Research, The University of Michigan.

Hoffman, L. W. (1972). Early childhood experiences and women's achievement motives. Journal of Social Issues, 28, 129-155.

Hoffman, L. W. (1977). Changes in family roles, socialization, and sex differences. American Psychologisi, 32, 644-657.

King, S. (1989). Sex differences in a casual model of career maturity. Journal of Counseling \& Development, 68, 208-214.

Kriger, S. F. (1972). Achievement and perceived parental child-rearing attitudes of career women and homemakers. Journal of Vocational Behavior, 2 , $419-432$.

Larson, J. H., Busby, D. M., Wilson, S., Medora, N., Allgood, S. (1994). The multidimensional assessment of career decision problems: The Career Decision Diagnostic Assessment. Journal of Counseling \& Development, 72 , $32 .-328$.

Larwood, L., \& Gutek, B. A. (1987). Working toward a theory of women's career development. In B. A. Gutek \& L. Larwood (Eds.), Women's career development (pp. 170-183). Newbury Park, CA: Sage.

Leslie, L. A. (1986). The impact of adolescent females' assessments of parenthood and employment on plans for the future. Journal of Youth and Adolescence, 15, $29-49$

Lopez, L. C., \& Staszkiewicz, M. J. (1985). Sex differences in internality externality. Psychological Reports, 57, 1159-1164.
Lunneborg, P. W. (1978). Sex and career decision-making styles. Journal of Counseling Psychology, 25, 299-305.

Maccoby, E. E., \& Jacklin, C. N. (1974). The psychology of sex differences. Stanford, CA: Stanford University.

Marcia, J. E. (1980). Identity in adolescence. In J. Adelson (Ed.), Handbook of adolescent psychology (pp. 159-187). New York: Wiley.

McGoldrick, M. (1987). On reaching mid-career without a wife. The Family Therapy Networker, 11(3), 32-39.

Miller, J. B. (1976). Toward a new psychology of women Boston, MA: Beacon.

Moreland, J. R., Harren, V. A., Krimsky-Montague, E., \& Tinsley, H. E. (1979) Sex role self-concept and career decision making. Journal of Counseling Psychology, 26, 329-336.

Newman, J. L., Fuqua, D. R., \& Seaworth, T. B. (1989). The role of anxiety in career indecision: Implications for diagnosis and treatment. The Career Development Quarterly, 37, 221-231.

O'Hare, M. M., \& Beutell, N. J. (1987). Sex differences in coping with career decision making Journal of Vocational Behavior, 31, 174-181.

O'Hare, M. M., \& Tamburri, E. (1986). Coping as a moderator of the relationship between anxiety and career decision making. Journal of Counseling Psychol ogy, 33, 255-264.

Osipow, S. H. (1980). Manual for the Career Decision Scale. Columbus, $\mathrm{OH}$ Marathon Consulting Press.

Osipow, S. H., Carney, C. G., Winer, J. L., Yanico, B., \& Koschir, M. (1976) The Career Decision Scale (3rd rev.). Columbus, $\mathrm{OH}$ Marathon Consulting Press.

Paludi, M. A., \& Fankell-Hauser, J. (1986). An idiographic approach to the study of women's achievement striving. Psychology of Women Quarterly, 10 , 89-100.

Parsons, J. E., \& Goff, S. B. (1980). Achievement motivation and values: An alternative perspective. In L. J. Fyans, Jr., (Ed.), Achievement motivation: Recent trends in theory and research (pp. 349-373). New York: Plenum Press.

Perun, P. J., \& Bielby, D. D. V. (1981). Towards a model of female occupational behavior. A human development approach. Psvcholog vo Women Quarterly, 6, 234-252.

Rosenberg, F. R., \& Simmons, R. B. (1975). Sex differences in the self-concept in adolescence. Sex Roles, 1, 147-159.

Slaney, R. B. (1988). The assessment of career decision making. In W. B. Walsh \& S. H. Osipow (Eds.), Career decision making (pp. 33-76). Hillsdale, NJ: Erlbaum.

Taylor, K. M. (1982). An investigation of vocational indecision in college students: Correlates and moderators. Journal of Vocational Behavior, 21 . 318-329.

Tittle, C. K. (1981). Careers and family: Sex roles and adolescent life plans Beverly Hills, CA: Sage

Tyler, L. E. (1965). The psychology of human differences. New York: AppletonCentury-Crofts.

Veroff, J. (1983). Contextual determinants of personality. Personality and Social Psychology Bulletin. 9, 331-343.

Ward, D. A., Seccombe, K., \& Bendel, R. (1988). Influenceability of sex differences under conditions of risk taking. The Journal of General Psychol ogy, $155,247-255$

Jeffry H. Larson is an associate professor in the Department of Family Sciences at Brigham Young University, Provo. Utah. Mark Butler is a doctoral student in the Department of Human Development and Family Studies at Texas Tech University, Lubbock. Stephan Wilson is an associate professor in the Research Center for Families and Children at the University of Kentucky, Lexington. Nilufer Medora is an associate professor in the Department of Home Economics at California State University, Long Beach. Scot Allgood is an assistant professor in the Department of Family and Child Development at Utah State University, Logan. This article is a revision of a paper presented at the International Conference on Gender and the Family, Brigham Young University, Provo, UT, February 1991. This research was supported by a grant from the Women's Research Institute, Brigham Young University, Provo, UT. Correspondence regarding this article should be sent to Jeffry $H$. Larson, 274 TLRB, Brigham Young University, Provo, UT 84602. 